Misca, G. (2014) The "Quiet Migration": Is Intercountry Adoption a Successful Intervention In the Lives of Vulnerable Children?. Family Court Review, 52: 60-68. doi: 10.1111/fcre.12070

\title{
The "Quiet Migration": Is Intercountry Adoption a Successful Intervention in the Lives of Vulnerable Children?
}

\author{
Gabriela Misca ${ }^{\mathrm{i}}$
}

\section{Abstract}

Over the past decades international adoption has become a global phenomenon involving cross-border movement of vulnerable children, mainly from poor, undeveloped countries to wealthier countries. Debates around international adoptions invoke often passionate arguments for and against. At times seen as 'the ultimate form of imperialism', trafficking and exploitation of children, international adoptions are also praised as successful interventions in the lives of the most vulnerable children worldwide. This paper draws on research findings on the outcomes of international adoption and its impact on various aspects of adopted children's development and identifies the gaps relating to evidencebased interventions best suited to the needs of these children post-international adoption. Keywords: inter-country adoption; child development; post-adoption support.

\section{Practitioner's Keypoints}

Based on the reviewed research findings, this paper supports the following arguments:

- overall, children adopted internationally can and do thrive in their adoptive countries; 


\section{This is a pre-print version:}

Misca, G. (2014) The "Quiet Migration": Is Intercountry Adoption a Successful Intervention In the Lives of Vulnerable Children?. Family Court Review, 52: 60-68. doi: 10.1111/fcre.12070

- $\quad$ such success is guaranteed by the high commitment of adoptive parents and the availability of post-adoption support services;

- there is, however, a lack of evidence-based practice relating to interventions best suited to the needs of these children post-international adoption;

- $\quad$ following a globally standardised process and strict protocols may help alleviate illicit activity in international adoptions;

- $\quad$ existing guidelines must be tightened to ensure that children are the central focus in intercountry adoption and that their development is not affected by cross-border movement.

\section{Intercountry adoption - a global phenomenon?}

Intercountry adoption, also referred to as international, overseas or cross-border adoption, encompasses the transfer of children across borders into a new and often wealthier country that embraces a different race, culture and language (Masson, 2001). This phenomenon of cross-border movement of children - aptly labelled by demographers the "quiet migration" (Weil, 1984) - typically involves the adoption of vulnerable and disadvantaged children in situations where poverty, abuse and neglect have become a significant part of their life (Cuthbert, 2012). Overseas adoption is accepted as legitimate only when the child is unable to be safely cared for by family members or adopted within country. Intercountry adoption in practice is expected to consider the best interests of the child and his/her human rights and usually prospective adopters have to be assessed and 


\section{This is a pre-print version:}

Misca, G. (2014) The "Quiet Migration": Is Intercountry Adoption a Successful Intervention In the Lives of Vulnerable Children?. Family Court Review, 52: 60-68. doi: 10.1111/fcre.12070

deemed suitable to assume the role (Department for Education, 2012). In most cases, intercountry adoption describes adoption of children from less developed countries into more developed countries.

The emergence of intercountry adoption as a movement of children across national borders is linked to the humanitarian response to rescue children after World War II in Europe, and following the Korean War in 1956 and Vietnam War in 1975 (Mather, 2007; Young, 2012). The increased prevalence of such cross-border movement of children has been linked to major social and political changes and "waves" of intercountry adoptions can be observed historically in conjunction with major social and political changes. For example, a peak in the number of intercountry adoptions of children from Eastern Europe was registered during the 1990s following the fall of the communist regimes in these countries; and over the past decade China has emerged as the major source of children worldwide resulting from its "one child policy". Intercountry adoption maintains its humanitarian scope, however, recently the perception is shifting towards seeing intercountry adoptions as driven by demand from prospective adopters from developed countries, particularly in the light of a number of 'celebrity' intercountry adoptions during 2005-2007 (Mezmur, 2009) which raised the profile of African countries as sources of children.

It is estimated that at its peak in 2004 , intercountry adoption involved 45,000 children worldwide (Selman, 2009) and approximately 410,000 children over the 20002010 decade (Selman, 2012). However, it is estimated that during 2004 to 2010 global numbers of intercountry adoptions declined to 29,000 , which is at a level comparable with 


\section{This is a pre-print version:}

Misca, G. (2014) The "Quiet Migration": Is Intercountry Adoption a Successful Intervention In the Lives of Vulnerable Children?. Family Court Review, 52: 60-68. doi: 10.1111/fcre.12070

that recorded in 1998 (Selman, 2010). Such figures need to be interpreted with caution as the actual extent of intercountry adoption is difficult to estimate accurately due to a lack of a central, unified system of recording intercountry adoptions worldwide (Selman, 2002).

\section{Legal benchmarks in intercountry adoption}

The 1989 UN Convention on the Rights of the Child (UNCRC) reinforces the best interests of the child and the need to ensure that adoption in the child's native country was considered before intercountry adoption (Wilkening, 2011). The convention embraces human rights as central to its aims in ensuring that children are treated fairly and experience a safe and stable childhood. The UNCRC later formed the basis of the 1993 Hague Convention on Intercountry Adoption which similarly aims to protect vulnerable children, and also their birth families, against the risks of illegal, irregular, premature or ill-prepared adoptions abroad (Smith Rotabi \& Gibbons, 2012). The Hague Convention reinforces the UNCRC and offers a comprehensive framework and ensures that intercountry adoptions are made in the best interests of the child and with respect for his or her fundamental rights, and to prevent the abduction, the sale of, or traffic in children. It also suggests that intercountry adoption is a necessary intervention for children for whom families cannot be identified in their native country (Wilkening, 2011). However, the Hague Convention has been criticized for its counter-productive nature, as it delays the formality of adoption especially when the best interests of the child cannot be achieved through in-country care (Abernethy, 2010) and for its bias towards Western culture that highlights the importance 


\section{This is a pre-print version:}

Misca, G. (2014) The "Quiet Migration": Is Intercountry Adoption a Successful Intervention In the Lives of Vulnerable Children?. Family Court Review, 52: 60-68. doi: 10.1111/fcre.12070

of addressing cultural concerns in the process of intercountry adoption (Willing, Fronek \& Cuthbert, 2012).

Notwithstanding the overarching international legal benchmarks, it is recognised that intercountry adoption is a complex process because of every country's independent laws and policy and the often lack of agreement between them in this respect. Despite intercountry adoption becoming a favourable method of achieving parenthood, the inherent challenge of differing social, political, economic and cultural factors that dominate each country emphasises the complexity of the adoption process (Young, 2012). Although different governments or laws do not necessarily hinder the ability to adopt children from abroad, it raises important issues for policy and practice, particularly emphasising the need for universal structure and formalised guidelines that all governments must follow in respect of intercountry adoptions.

\section{Debates in intercountry adoption}

Debates around international adoptions invoke often passionate arguments for and against. The inevitable question that must be answered is whether intercountry adoption is an intervention which promotes the best interests of vulnerable children (Cuthbert, 2012) worldwide. This question has received ample consideration and has raised much controversy. This section will explore the debates surrounding the issue of children's intercountry adoption in an attempt to offer further insight in to such question. 
Misca, G. (2014) The "Quiet Migration": Is Intercountry Adoption a

Successful Intervention In the Lives of Vulnerable Children?. Family

Court Review, 52: 60-68. doi: 10.1111/fcre.12070

\section{Benefits of intercountry adoption}

One side of the debate considers the benefits intercountry adoption provides globally and the potential implications that the benefits have on the child's development. The intercountry adoptions have increased considerably as a result of decreased numbers of healthy children available for adoption in developed countries (Fronek \& Cuthbert, 2012). Inherent challenges of domestic adoption along with decreased birth rates and the high cost of infertility treatment, use of contraceptive methods, and increased lone parent support are factors that both independently and collectively contribute to the upward trend of intercountry adoption (Herrmann, 2010). In addition, high poverty, lack of contraception, child policy rules and increased birth rates in poorer nations promote higher rates of intercountry adoption (Masson, 2001) by providing supply to the increasing demand for children from childless couples in developed countries (Herrmann, 2010).

However, the benefits do not solely help the prospective parents achieve parenthood, but also offer real benefits for children from countries where the number of orphaned children significantly outweighs the number of adoptive parents, thus increasing their chances of experiencing a stimulating and nurturing upbringing. Despite the benefits and success of many intercountry adoptions, there is a continuing argument that intercountry adoption should be considered as a last resort and all other options including allowing the child's extended family to assume the adoptive role should be first priority (Young, 2012). 
Misca, G. (2014) The "Quiet Migration": Is Intercountry Adoption a Successful Intervention In the Lives of Vulnerable Children?. Family Court Review, 52: 60-68. doi: 10.1111/fcre.12070

\section{In whose best interest?}

Critics dispute that intercountry adoption is maintaining its central focus on the best interests of the child, arguing that the process has shifted to meet the demands of prospective adoptive parents in more developed and rich countries. The increased desire and economic power of individuals and couples in Western countries to adopt, coincides with higher rates of abandoned children in less developed countries (Fronek \& Cuthbert, 2012 ) and thus the process is perceived as a "business" that caters for prospective adopters rather than the best interest of the child (Wilkening, 2011). The difficulties in ensuring that the best interests of children are paramount, despite the safeguards of the Hague Convention are notorious in practice. The shift in focus from helping children by finding them families willing to adopt them, to a system that operates to provide a service for Western couples increases commercialism and profit, and arguably creates the "ultimate form of imperialism' (Young, 2012) which raises questions about the real motives behind intercountry adoption. Even in cases of natural disasters where adoption of foreign children has helped accommodate them in stable families, the benefits of removing children from their native country still continues to raise controversy. For example, in the aftermath of the Haiti earthquake in 2010, calls for intercountry adoption processes to be expedited raised subsequent questions about the legitimacy of Haitian children being removed from their families (Selman, 2011). 
Misca, G. (2014) The "Quiet Migration": Is Intercountry Adoption a Successful Intervention In the Lives of Vulnerable Children?. Family Court Review, 52: 60-68. doi: 10.1111/fcre.12070

\section{Child laundering}

Intercountry adoption is often hampered by illicit activities such as human trafficking and the exploitation of children. The increased demand of children from developing countries has, at times, turned intercountry adoption into a cover for illicit movement of vulnerable children (Herrmann, 2010). Thus, many vulnerable children become victims of child laundering where they are illegally separated from their birth families and processed through the adoption system as "orphans" (Smolin, 2005, 2006). Acknowledging the illegal movement of children underlines the importance of ethical and legal considerations that cannot be ignored, particularly as intercountry adoption operates on the premise of protecting children from further harm (Fronek \& Cuthbert, 2012).

Although efforts to prevent "child laundering" are enforced (Mather, 2007) and the Hague Special Commission of June 2010 devoted special attention to the issue of 'trafficking', (Hague Conference on Private International Law, 2010) poor legislation and regulation of some Governments enables these acts to filter through the system unnoticed with massive implications for the child (Davies, 2011). In this respect, the significant drop in intercountry adoptions between 2004 and 2010 has been interpreted by some authors to be a result of poorer countries reacting to the corruption engendered in intercountry adoption and calling for its fundamental reform (Smolin, 2010). 
Misca, G. (2014) The "Quiet Migration": Is Intercountry Adoption a Successful Intervention In the Lives of Vulnerable Children?. Family Court Review, 52: 60-68. doi: 10.1111/fcre.12070

\section{Cultural and self-identity}

Even in the absence of such illicit and harmful activities, intercountry adoption is criticized as it ultimately involves removing a child from their cultural roots, (Davies, 2011) which is believed to have significant implications on the child's development and well-being throughout the course of life. The traditional belief that to children, race and colour are unimportant as they possess 'colour blindness' with respect to their disparate ethnicity to their adoptive family, has been contradicted by evidence that in certain communities race and ethnicity are considered important factors (Davies, 2011).

Intercountry adoption is often criticized because adopted children's identities are lost and replaced by a new name and a new nationality when they are assimilated in to their adoptive country (Abernethy, 2010). However in certain countries, such as England, strict guidelines are followed to ensure that adopted children are matched as closely as possible to their adoptive families. But, ethnicity and race matching are increasingly deemed less important and priority is given to finding a placement that will meet the child's needs and avoid delays in doing so (Unwin \& Misca, 2013).

\section{Development, risks, and resilience in intercountry adoptees}

Notwithstanding the on-going and passionate debates surrounding the intercountry adoptions, the outcomes for children being adopted are the issue at the heart of the question of whether intercountry adoption is a successful intervention into the lives of children. 


\section{This is a pre-print version:}

Misca, G. (2014) The "Quiet Migration": Is Intercountry Adoption a Successful Intervention In the Lives of Vulnerable Children?. Family Court Review, 52: 60-68. doi: 10.1111/fcre.12070

Thus, it is very important to distinguish how intercountry adoption really affects the development and adjustment of children who experience intercountry adoption. This section will draw on findings of research and meta-analyses on the development of children adopted internationally.

Since intercountry adoption became a frequent occurrence globally, research studies exploring the developmental trajectories of children adopted internationally have been conducted over the decades. Early studies of intercountry adoption (reviewed by Tizard, 1991) support an overall optimistic view of children's development following intercountry adoption. The vast majority of intercountry-adopted children and adolescents were reported as functioning well. There is usually a process of 'remarkable' recovery and developmental catch up for children in their first year after adoption and the vast majority of adoptive parents rate their satisfaction with adoption as high or very high (Thoburn \& Chales, 1992; Tizard, 1991).

Some of the challenges presented during the early stages were related to children having to un-learn certain "surviving techniques" that they used in their previous environments, such as lying or stealing. Some adoptive parents had to re-parent children and adoptive parents of previously abused children had to help these children to reconsider their perceptions of adults as harmful. 
Misca, G. (2014) The "Quiet Migration": Is Intercountry Adoption a Successful Intervention In the Lives of Vulnerable Children?. Family Court Review, 52: 60-68. doi: 10.1111/fcre.12070

\section{Risk and resilience}

A particular group of international adoptees has received special attention from the research and practitioner communities worldwide are the children adopted from Romanian orphanages in the early 1990s. The unique feature of this group of intercountry adoptees is that the majority of Romanian children spend variable amounts of time in institutional care in very impoverished environments and thus researchers seized the opportunity to study such a unique 'natural experiment' of child development after rescue from extreme deprivation. The research studies conducted in recipient countries of such Romanian children - the USA, Canada, England, the Netherlands - have made a significant contribution to our understanding of development and resilience in children who suffered early deprivation followed by good quality family rearing, which is often the case in intercountry adopted children (Misca, 2013).

Importantly, these research studies have highlighted a series of risk factors that may explain the developmental outcomes of children adopted internationally. Among these are: the child's age at adoption and type of early experiences before adoption as well as medical and social history prior to birth. For example, research suggests that emotional and behavioural difficulties seem more likely to occur when children are adopted at a relatively late age and adverse conditions prior to adoption such as poverty, malnutrition, institutionalisation, neglect and abuse predict poor outcomes (Rutter et al., 2011).

Child's age at adoption has significant implications on the development of executive functioning, language and the sensory processing and attention (Jacobs, Miller 


\section{This is a pre-print version:}

Misca, G. (2014) The "Quiet Migration": Is Intercountry Adoption a Successful Intervention In the Lives of Vulnerable Children?. Family Court Review, 52: 60-68. doi: 10.1111/fcre.12070

\& Tirella, 2009). Combined with long-term placement in an institution can also increase the risks of poor emotional control and similarly increase both internalising and externalising behavioural problems (Barcons-Castel, Fornieles-Dell \& Costas-Moragas, 2011). On the other hand, Cohen et al. (2008) suggest that long-term deprivation may have severe implications on the physical development of children and potentially have more irreversible damage in comparison to cognitive development.

Mother's age, nutrition and substance mis-use during pregnancy will also influence the outcomes post intercountry adoption. Such risk factors have been identified by research on special needs domestic adoptions as well (Winkler, 2007), and seen to influence the child's development post-adoption both solely and in interaction with each other. However, in intercountry adoption situations it is likely that the information about the existence of such risk factors may not be available, thus hindering the process of post-adoption support (Misca, 2013). This lack of information on children's background and experiences prior to intercountry adoption represents a major challenge for adoptive parents and post-adoption support services alike (Palacios, 2009).

Despite such limitations, intercountry adoptions have relatively low breakdown rates and research has highlighted some of the key factors that may account for intercountry adoptions success. These refer mainly to the adoptive parents' commitment, the quality of parenting and family environment they provide and the high level support provisions in their adoptive countries, including health, mental heath and educational postadoption support (Misca, 2013). 


\section{This is a pre-print version:}

Misca, G. (2014) The "Quiet Migration": Is Intercountry Adoption a Successful Intervention In the Lives of Vulnerable Children?. Family Court Review, 52: 60-68. doi: 10.1111/fcre.12070

Whilst many children display remarkable resilience toward their negative life events prior to adoption, this is not always the case, and in some circumstances children show long-term effects of deprivation (Greene et al., 2008). Moreover, research studies with Chinese children adopted abroad show that developmental progress may be inhibited and as a result delayed because of early deprivation. For example, Chinese adopted children displayed average development in the first six months of life, although their development and all-around performance was typically not as good as non-adopted children of the same age until they had reached two years old (Cohen et al, 2008). This finding has important implications for how developmental outcomes of intercountry adoptees are assessed: if intercountry adopted children take approximately two years to reach equal, if not better, performance than their non-adoptive peers, perhaps this should be applied as a bench mark for the average adjustment time for intercountry adoption, and should be used as a guideline for child adjustment before children are assumed to be underdeveloped. Moreover, it appears that early adoption is beneficial for children's physical development, attachment and school performance, but later adoption is detrimental to their overall development and adjustment (Ijzendoorn \& Juffer, 2006).

\section{Developmental outcomes}

Research exploring the effects on the child considers the three dimensional processes of development: cognitive, physical and socio-emotional. Children's cognitive development has received much attention as it has important implications for children's 


\section{This is a pre-print version:}

Misca, G. (2014) The "Quiet Migration": Is Intercountry Adoption a Successful Intervention In the Lives of Vulnerable Children?. Family Court Review, 52: 60-68. doi: 10.1111/fcre.12070

education and their ability to progress in school in their adoptive country. For example, a meta-analysis of 62 studies explored the cognitive development of adopted children, institutionalized children, children who remained with their birth families and non-adopted siblings (Ijzendoorn, Juffer \& Poelhuis, 2005). Adopted children displayed the highest IQ test scores and better school performance compared to their non-adopted siblings who stayed behind in their native country. However, adopted children also displayed poor language and increased learning difficulties in comparison to their environmental, nonadopted peers; although their general cognitive ability was unaffected there is an increased risk of language impairment (Hough \& Kaczmarek, 2011; Ijzendoorn, Juffer \& Poelhuis, 2005; Scott, Roberts, \& Glennen, 2011). This suggests that whilst the intercountry adoptees' cognitive development improved in comparison to their non-adopted siblings, when compared to their environmental peers, in their adoptive countries, their development remains lower.

Research findings also acknowledge that children who are internationally adopted are at higher risk of developing mental health problems, particularly concerning behavior and emotional control. Wiik et al. (2011) highlighted an increased number of reports of Attention Deficit Hyperactivity Disorder (ADHD) amongst post-institutionalised children who have been internationally adopted, and higher reports of externalizing and internalizing behaviour problems (Barcons-Castel, Fornieles-Dell \& Costas-Moragas, 2011).

In addition, social, behavioural behavioral and emotional development is reported as inhibited in intercountry adopted children (Barcons-Castel, Fornieles-Dell \& Costas- 


\section{This is a pre-print version:}

Misca, G. (2014) The "Quiet Migration": Is Intercountry Adoption a Successful Intervention In the Lives of Vulnerable Children?. Family Court Review, 52: 60-68. doi: 10.1111/fcre.12070

Moragas, 2011). Research indicates that children adopted intercountry are less likely to form intimate relationships and are significantly more likely to live independently in adulthood (Tieman, van der Ende \& Verhulst, 2006). Although there is limited evidence as yet about the attachment and development of adults who have been adopted as children from across country borders, predictions of poor social interaction, relationship formation and intimacy in adulthood are based on the premise that these are a result of early attachment problems. However, Welsh et al. (2007) argued that such assumption is flawed and that attachment disorders which are identified in intercountry adopted children are over diagnosed, and that it is impractical to generalise this to all children adopted internationally.

\section{Cultural and self-identity}

The issues of cultural and self-identity development in intercountry adoptees are thought to become increasingly relevant as the adoptees enter their adolescent years (Verhulst, 2000). Early studies of intercountry adoptees highlighted that adoptees regard themselves as having the same national identity as those born in the country where they live and, while many show a strong interest in their backgrounds (Irhammar \& Cederblad, 2000), some want to distance themselves from immigrants of a similar ethnic background (Saetersdal \& Dalen, 2000). This was found to be particularly true in countries where there is ethnic stereotyping and discrimination against the children's original ethnic groups - for example this has been reported in relation to Romanian children adopted in Ireland (Greene et al., 2007). Successful adjustment has been noted in intercountry adoptees whose parents 


\section{This is a pre-print version:}

Misca, G. (2014) The "Quiet Migration": Is Intercountry Adoption a Successful Intervention In the Lives of Vulnerable Children?. Family Court Review, 52: 60-68. doi: 10.1111/fcre.12070

are open about the ethnic issues. For example, research with Romanian young people who were adopted in England as children (Beckett et al., 2008) reported that they are more inclined to want to visit their native country, although they classified themselves as English post-adoption. Others, however, felt that they were still Romanian and reported high rates of depression and 'lost identity' (Beckett et al., 2008).

A meta-analytical review across 88 research studies showed that there is no significant difference in self-esteem between adoptees and non-adoptees, and this held true for international, domestic and transracial adoptees (Juffer \& van IJzendoorn, 2007). This may suggest that ethnic and cultural identity issues are not as salient as first thought for these young people's adjustment. However this assertion needs to be interpreted within the current context of globalization and the declining importance of national borders. As foreign children are adopted in increasingly ethnically and culturally diverse societies and families, it is thus conceivable that the issues of ethnic and cultural identity for intercountry adoptees may not manifest in the same way as previously thought. Therefore, further investigation is warranted.

\section{Conclusions}

In light of the reviewed research findings, it is clear that children adopted internationally can and do thrive in their adoptive countries, and that the negative outcomes of intercountry adoption are not necessarily unique to cross-border adoption per se but may be explained by individual differences in how children are able to cope with their early 


\section{This is a pre-print version:}

Misca, G. (2014) The "Quiet Migration": Is Intercountry Adoption a Successful Intervention In the Lives of Vulnerable Children?. Family Court Review, 52: 60-68. doi: 10.1111/fcre.12070

adverse experiences. While research indicates that international adoptions are successful overall with very low breakdown rates, such success is guaranteed as a result of the high commitment of adoptive parents (despite some isolated cases that occasionally attract negative publicity ${ }^{\mathrm{ii} 12}$ ). Therefore, there is a clear need for post-adoption support (Wilkening, 2011). The availability of support services (health, mental health and educational) for these children in their adoptive countries and the cost implications need to be considered in relation to intercountry adoptees. The research identifies the lack of evidence-based practice relating to interventions best suited to the needs of these children post-international adoption (Welsh et al, 2007), and highlights the valuable lessons that can be learned and applied to other 'at-risk' children.

The passionate debates surrounding the issue of intercountry adoption highlight that in order for overseas adoption to continue to succeed, the relationship between sending and receiving countries must be strengthened (Smith Rotabi \& Gibbons, 2012). Following a globally standardized process that follows strict protocol may help alleviate illicit activity (Davies, 2011). Thus, existing guidelines must be tightened to ensure that children are the central focus in intercountry adoption and that their development is not affected by crossborder movement (Cuthbert, 2012). Overall, the Hague Convention provides a good framework to guide international policy and practice, however in the absence of strong, universal regulations and trusting relationships between governments, successful

\footnotetext{
${ }^{2}$ In April 2010, American adoptive mother Torry Ann Hansen put seven year-old, Russian-born Artyom on a plane back to Russia, alone, and with a note stating that "[a]fter giving my best to this child, I am sorry to say that for the safety of my family, friends and myself, I no longer wish to parent this child." (Levy, 2010).
} 


\section{This is a pre-print version:}

Misca, G. (2014) The "Quiet Migration": Is Intercountry Adoption a Successful Intervention In the Lives of Vulnerable Children?. Family Court Review, 52: 60-68. doi: 10.1111/fcre.12070

intervention cannot be achieved (Smith Rotabi \& Gibbons, 2012). Extra efforts to strengthen this convention may enhance the success of intercountry adoption as a successful intervention in the lives of vulnerable children worldwide.

The changing global landscape in which intercountry adoption currently operates may aid to remove some of its stigmatizing connotations and further research on the outcomes for internationally adopted children, which is highly relevant for both policy and practice. As many of these children had experienced adversity (including war, severe poverty, malnutrition, institutionalization, abuse) in their birth countries, following their progress in their adoptive countries is crucial for understanding their development, guiding policy and practice, and for shedding light on the issue of developmental trajectories of other 'at-risk' children. 
Misca, G. (2014) The "Quiet Migration": Is Intercountry Adoption a Successful Intervention In the Lives of Vulnerable Children?. Family Court Review, 52: 60-68. doi: 10.1111/fcre.12070

\section{References}

Abernethy, S. (2010). Intercountry kinship adoptions: limits to the Hague

Convention on the Protection of Children and Intercountry Adoption. Kotuitui: New Zealand Journal of Social Sciences, 5(1), 26-40.

Barcons-Castel, N., Fornieles-Deu, A., \& Costas-Moragas, C. (2011).

International adoption: Assessment of adaptive and maladaptive behavior of adopted minors in Spain. The Spanish Journal of Psychology, 14(1), 123-132.

Beckett, C., Hawkins, A., Rutter, M., Castle, J., Colvert, E., Groothues, C., ... Sonuga-Barke, E. (2008). The importance of cultural identity in adoption: A study of young people adopted from Romania. Adoption \& Fostering, 32(3), 9-22.

Cohen, N.J., Lojkasek, M., Zadeh, Z.Y., Pugliese, M., \& Kiefer, H. (2008).

Children adopted from China: A prospective study of their growth and development. Journal of Child Psychology and Psychiatry, 49(4), 458-468.

Cuthbert, D. (2012). Introduction: Waiting for a better world: critical and interdisciplinary perspectives on intercountry adoption. Social Policy and Society, 11(3), 375-380. 
Misca, G. (2014) The "Quiet Migration": Is Intercountry Adoption a Successful Intervention In the Lives of Vulnerable Children?. Family Court Review, 52: 60-68. doi: 10.1111/fcre.12070

Davies, M. (2011). Intercountry adoption, children's rights and the politics of rescue. Adoption \& Fostering, 35(4), 50-62.

Department for Education (2012). Intercountry Adoption. Retrieved June

3 , 2013 , from: http://www.education.gov.uk/childrenandyoungpeople/families/adoption/intercou ntryadoption.

Fronek, P., \& Cuthbert, D. (2012). History repeating... disaster-related intercountry adoption and the psychosocial care of children. Social Policy and Society, 11(3), 429-442.

Greene, S., Kelly, R., Nixon, E., Kelly, G., Borska, Z., Murphy, S., \& Daly, A. (2008). Children's recovery after early adversity: Lessons from intercountry adoption. Child Care in Practice, 14(1), 75-81.

Greene, S., Kelly, R., Nixon, E., Kelly, G., Borska, Z., Murphy, S., Daly, A., Whyte, J., \& Murphy, C. (2007), A study of intercountry adoption outcomes in Ireland.

Hague Conference on Private International Law. (2010). Conclusions and recommendations of the special commission of June 2010. Retrieved from http://www.hcch.net/upload/wop/adop2010concl_e.pdf. 
Misca, G. (2014) The "Quiet Migration": Is Intercountry Adoption a Successful Intervention In the Lives of Vulnerable Children?. Family Court Review, 52: 60-68. doi: 10.1111/fcre.12070

Herrmann, K. (2010). Reestablishing the humanitarian approach to adoption: the legal and social change necessary to end the commodification of children. Family Law Quarterly, 44(3), 409-428.

Hough, S. D., \& Kaczmarek, L. (2011). Language and reading outcomes in $\quad$ young children adopted from eastern european orphanages. Journal of Early Intervention, 33(1), 51-74.

Ijzendoorn, M.V.V., Juffer, F., \& Poelhuis, C.W.K. (2005). Adoption and cognitive development: a meta-analytic comparison of adopted and nonadopted children's IQ and school performance. Psychological Bulletin, 131(2), 301-316.

Ijzendoorn, M.V.V., \& Juffer, F. (2006). The Emanuel Miller Memorial Lecture 2006: Adoption as intervention. Meta-analytic evidence for massive catch-up and plasticity in physical, socio-emotional, and cognitive development. Journal of Child Psychology and Psychiatry, 47(12), 1128-1245.

Irhammar, M. \& Cederblad, M. (2000). Outcome of intercountry adoption in Sweden. In P. Selman (Ed.), Intercountry Adoption: Developments, trends and perspectives. London: BAAF. 
Misca, G. (2014) The "Quiet Migration": Is Intercountry Adoption a Successful Intervention In the Lives of Vulnerable Children?. Family Court Review, 52: 60-68. doi: 10.1111/fcre.12070

Jacobs, E., Miller, L.C., \& Tirella, L.G. (2010). Developmental and behavioural performance of internationally adopted preschoolers: a pilot study. Child Psychiatry Human Development, 41, 15-29.

Juffer, F., \& Ijzendoorn, M.H.V. (2007). Adoptees do not lack self-esteem: a meta-analysis of studies on self-esteem of transracial, international, and domestic adoptees. Psychological Bulletin, 133(6), 1067-1083.

Levy, C. (2010, April 9). Russia calls for halt on U.S. adoptions. The New York Times, pp. 1, 2. Retrieved from http://www.nytimes.com/http://www.nytimes.com/2010/04/10/world/europe/10ru $\underline{\text { ssia.html }}$

Masson, J. (2001). Intercountry adoption: a global problem or a global solution. Journal of International Affairs, 55(1), 141-166.

Mather, M. (2007). Intercountry adoption. archives of disease in childhood, $92(6), 479-482$.

Mezmur, B. D. (2009). From Angelina (to adonna) to oe's ark: what arethe 'A-Z' lessons for intercountry adoptions in frica?. InternationalJournal of Law, Policy and the Family, 23(2), 145-173. 
Misca, G. (2014) The "Quiet Migration": Is Intercountry Adoption a Successful Intervention In the Lives of Vulnerable Children?. Family Court Review, 52: 60-68. doi: 10.1111/fcre.12070

Misca, G. (2013). The 'Quiet Migration': hallenges for families with children adopted internationally. In A. Abela and J. Walker (Eds.), Contemporary Issues in Family Studies: Global Perspectives on Partnerships, Parenting and Support in a Changing World. Chichester: Wiley.

Palacios, J. (2009). The ecology of adoption. In G. M. Wrobel and E. Neil (Eds.), International Advances in Adoption Research for Practice (71-94). Chichester: Wiley.

Kumsta, R., Kreppner, J., Rutter, M., Beckett, C., Castle, J., Stevens, S., \& Sonuga-Barke, E. J. (2010). Deprivation-specific psychological patterns: effects of institutional deprivation. Monographs of the Society for Research in Child Development, 75(1), 48-78.

Saetersdal, B. \& Dalen, M. (2000). Identity formation in a homogeneouscountry: Norway. In P. Selman (Ed.), Intercountry Adoption: Developments, $\quad$ trends and perspectives (164-179). London: BAAF

Selman, P. (2002). Intercountry adoption in the new millennium: the 'quiet migration' revisited. Population Research and Policy Review, 21(3), 205225. 
Misca, G. (2014) The "Quiet Migration": Is Intercountry Adoption a Successful Intervention In the Lives of Vulnerable Children?. Family Court Review, 52: 60-68. doi: 10.1111/fcre.12070

Selman, P. (2009). From Bucharest to Beijing: changes in countries sending children for international adoption 1990 to 2006. In G. M. Wrobel and E. Neil (Eds.), International Advances in Adoption Research for Practice (41-70). Chichester: Wiley.

Selman, P. (2010). Intercountry adoption in Europe 1998-2008: Patterns, trends Adoption \& Fostering, 34(1), 4-19

Selman, P. (2011). Intercountry adoption after the Haiti earthquake: Rescue or robbery? Adoption \& Fostering, 35(4), 41-49.

Selman, P. (2012). The global decline of intercountry adoption: What lies ahead? Social Policy and Society, 11, 381-397. doi:10.1017/S1474746412000085

Scott, K.A., Roberts, J.A., \& Glennen, S. (2011). . Journal of Speech, Language, and Hearing Research. 54, 1153-1169How well do children who are internationally adopted acquire language? A meta-analysis.

Smith Rotabi, K., \& Gibbons, J.L. (2012). Does the Hague Convention on Intercountry Adoption adequately protect orphaned and vulnerable children and their families? Child Family Studies, 21, 106-119. 
Misca, G. (2014) The "Quiet Migration": Is Intercountry Adoption a Successful Intervention In the Lives of Vulnerable Children?. Family Court Review, 52: 60-68. doi: 10.1111/fcre.12070

Smolin, D. M. (2005). Intercountry adoption as child trafficking, Valparaiso Law Review, 39(2), 281-325.

Smolin, D. M. (2006). Child laundering: How the intercountry adoption system legitimizes and incentivizes the practices of buying, trafficking, kidnaping, and stealing children. Wayne L. Rev., 52(113) 112-200.

Smolin, D. (2010). Child laundering and the Hague Convention on Intercountry Adoption: The future and past of intercountry adoption, University of Louisville Law Review, 48, 441-98.

Tieman, W., van der Ende, J., \& Verhulst, F.C. (2006). Social functioning of young adult intercountry adoptees compared to nonadoptees. Social Psychiatry Epidemology, 41, 68-74.

Tizard, B. (1991). Intercountry adoption-A review of the evidence, Journal of Child Psychology and Psychiatry and Allied Disciplines, 32(5): 743-756.

Thoburn, J. \& Charles, M. (1992). Inter-departmental review of adoption law: A review of research which is relevant to intercountry adoption, Background Paper No. 3, Jan. (Department of Health, Welsh Office and Scottish Office). 
Misca, G. (2014) The "Quiet Migration": Is Intercountry Adoption a Successful Intervention In the Lives of Vulnerable Children?. Family Court Review, 52: 60-68. doi: 10.1111/fcre.12070

Unwin, P. \& Misca, G. (2013). The changing face of adoption in England:

Opportunities and dilemmas, Revista de Asistenta Sociala, 12(2), 1-9.

Verhulst, F. C. (2000). Internationally adopted children: The Dutch longitudinal adoption study. Adoption Quarterly, 4(1), 27-44.

Welsh, J.A., Viana, A.G., Petrill, S.A., \& Mathias, M.D. (2007). Interventions for internationally adopted children and families: A review of the literature. Child and Adolescent Social Work Journal, 24(3), 285-311.

Wiik, K.L., Loman, M.M., Ryzin, M.J.V., Armstrong, J.M., Essex, M.J., Pollak, S.D., \& Gunnar, M.R. (2011). Behavioral and emotional symptoms of postinstitutionalized children in middle childhood. Journal of Child Psychology and Psychiatry, 52(1), 56-63.

Willing, I., Fronek, P., \& Cuthbert, D. (2012). Review of sociological literature on intercountry adoption. Social Policy and Society, 11(3), 465-479.

Wilkening, J.L. (2011). Intercountry adoption act ten years later: The need for post-adoption requirements. Ohio State Law Journal, 72(5), 1043-1068. 
Misca, G. (2014) The "Quiet Migration": Is Intercountry Adoption a Successful Intervention In the Lives of Vulnerable Children?. Family Court Review, 52: 60-68. doi: 10.1111/fcre.12070

Winkler, P.C. (2007). Domestic and international adoption. Social Work, 52(2), 189-190.

Young, A. (2012). Developments in intercountry adoption: From humanitarian aid to market-driven policy and beyond. Adoption \& Fostering, 36(2), 67-78.

Weil, R. (1984). International adoptions: the quiet migration, International Migration Review, 18(2): 276-290.

About the author:

Gabriela Misca (PhD, CPsychol, FHEA) is a Developmental Psychologist and Senior Lecturer in the Institute of Health and Society at the University of Worcester, England, UK. Her long standing research interests are within the applied developmental psychology field, having studied, researched and taught in the interdisciplinary fields of child and adolescent development and their interface with social work, social policy and practice. Dr Misca is currently actively pursuing a research portfolio in the specialist areas of resilience in child abuse and neglect, attachment and non-parental child care, inter-country adoption and same-gender parenting.

\footnotetext{
i Correspondence to: G.misca@worc.ac.uk
} 